$1-1-1974$

\title{
A survey of meat slaughtering and processing in West Virginia
}

John P. Kuehn

Follow this and additional works at: https://researchrepository.wvu.edu/ wv_agricultural_and_forestry_experiment_station_bulletins

\section{Digital Commons Citation}

Kuehn, John P., "A survey of meat slaughtering and processing in West Virginia" (1974). West Virginia Agricultural and Forestry Experiment Station Bulletins. 631.

https://researchrepository.wvu.edu/wv_agricultural_and_forestry_experiment_station_bulletins/541 @ WVU. It has been accepted for inclusion in West Virginia Agricultural and Forestry Experiment Station Bulletins by an authorized administrator of The Research Repository @ WVU. For more information, please contact ian.harmon@mail.wvu.edu. 


\section{[Blank Page in Original Bulletin]}




\section{SUMMARY}

This study is part of a series of reports on the West Virginia livestock industry. The objectives were to determine the magnitude and importance of the State's meat slaughtering and processing establishments and to survey the marketing procedures and practices of these firms.

Personnel of 125 of the 126 slaughtering and processing establishments in West Virginia were interviewed. These plants were each classified into one of six different categories: (1) licensed commercial slaughterer-processors; (2) licensed commercial slaughterers; (3) licensed commercial processors; (4) licensed commercial ham and bacon processors; (5) custom slaughterhouses; and (6) custom processing plants.

Most of the slaughtering and processing in West Virginia was for wholesale and retail trade rather than for private custom services. However, custom slaughtering did account for an average of 24 per cent of the total State slaughter, and custom processing accounted for an average of 18 per cent of the total number of animals processed in West Virginia in 1971. Custom slaughtering and processing, however, is a service for an individual who owns the livestock. The slaughterer or processor, in this case, does not buy livestock from one particular source before he processes and sells it to another, as is the practice when self-slaughtering and processing.

The State's meat slaughtering and processing plants acquired most live animals from auctions, farmers, and by raising their own animals, whereas processors most commonly acquired carcasses from commercial wholesalers and their own slaughter plants.

The processors' major outlets for processed and packed meat, in addition to providing custom services, included retail stores owned by processors, restaurants, drive-ins, hotels and motels, institutions, jobbers and wholesalers, and chain stores.

West Virginia is a deficit producer of meat and meat products. Only 18 per cent of the meat consumed in the State was processed there. Furthermore, a proportion of the animals processed was slaughtered outside the State. Thirty-two per cent of the cattle and 12 per cent of the hog carcasses were brought in from outside sources to be processed.

There seems to be potential in the State for an increase in the size of the meat slaughtering and processing industry as well as in the live animal production sector. 
[Blank Page in Original Bulletin] 


\section{Contents}

Introduction $\ldots \ldots \ldots \ldots \ldots \ldots \ldots \ldots \ldots \ldots \ldots \ldots \ldots$

The Questionnaire $\ldots \ldots \ldots \ldots \ldots \ldots \ldots \ldots \ldots \ldots \ldots$

Locations of Slaughtering and Processing Establishments ..... 7

Number of Animals Slaughtered and Processed . . . . . . 7

Primary Sources of Live and Slaughtered Livestock........ 8

Primary Outlets for Packed Processed Meat ........... 9

Production Versus Consumption of Meat in West Virginia...... 10

FIGURE 1 and TABLES $1-15 \ldots \ldots \ldots \ldots \ldots \ldots \ldots \ldots \ldots$

Literature Cited . . . . . . . . . . . . . . . . . 29

APPENDIX $\ldots \ldots \ldots \ldots \ldots \ldots \ldots \ldots \ldots \ldots \ldots \ldots \ldots \ldots \ldots \ldots \ldots$ 


\title{
THE AUTHOR
}

John P. Kuehn is Assistant Agricultural Economist.

\section{ACKNOWLEDGMENT}

The author expresses appreciation to Mr. Ernest Goff, Research Assistant in the Division of Resource Management, for administering the questionnaire to every respondent in this study.

\author{
West Virginia University \\ Agricultural Experiment Station \\ College of Agriculture and Forestry \\ Homer C. Evans, Acting Director \\ Morgantown
}




\section{A Survey of Meat Slaughtering And Processing in West Virginia}

\section{JOHN P. KUEHN}

A series of studies of the State's livestock industry has been conducted by the West Virginia University Agricultural Experiment Station. The economic aspects of feeder calf production, livestock auctions, livestock transportation, and other facets of livestock marketing have been under continuous study.

The objectives of this study were to determine the magnitude and importance of West Virginia's meat slaughterers and processors and to survey the marketing procedures and practices of these firms.

In order to accomplish these objectives, all but one of the West Virginia meat slaughterers and processors listed with the West Virginia Department of Agriculture were personally interviewed. The complete list consisted of 126 establishments, each fitting under one of six different categories: (1) licensed commercial slaughterer-processors; (2) licensed commercial slaughterers; (3) licensed commercial processors; (4) licensed commercial ham and bacon processors; (5) custom slaughterhouses; and (6) custom processing plants.

These categories are defined in the West Virginia Code:

Commercial Slaughterer. a person engaged for profit in this State in the business of slaughtering or dressing animals for human consumption which are to be sold or offered for sale through a commerical outlet or establishment, and shall include a person who, in addition to such commercial slaughtering, also engages in the business of a custom slaughterer; ${ }^{1}$

Custom Slaughterer. a person engaged for profit in this State in the business of slaughtering or dressing animals for human consumption which are not to be sold or offered for sale through a commercial outlet, commercial establishment, distributor, or to an individual, and shall include the boning or cutting up of carcasses of such animals and the grinding, chopping and mixing of the carcasses thereof; ${ }^{2}$

1 West Virginia Code, Chapter 19, Article 2-B, Section 2, Volume 7, 1971 Replacement Volume, Charlottesville, Virginia, The Michie Company, 1971, p. 353.

2lbid. 
Processor. a person who engages for profit in this State in the business of packing or packaging carcasses, meat, meat food products, or meat by-products for human consumption or a person engaged for profit in the business of curing, salting, smoking, processing, or other preparation of carcasses, meat, meat food products, or meat byproducts for human consumption; ${ }^{3}$

Commercial Processor. a processor for commercial outlets or distributors and shall include the business of custom processing; ${ }^{4}$

Custom Processor. a processor in which the meat, meat food products, or meat by-products derived through processing cannot be sold or offered for sale through a commercial outlet, commercial establishment, distributor, or to an individual, ${ }^{5}$

All processors and slaughterers must be properly licensed by the Commis. sioner of Agriculture. A fee is charged based on the average annual number of animals slaughtered and/or processed. Each establishment is inspected for cleanliness and sanitary conditions. The equipment must be of a "proper" nature and the Commissioner must be "satisfied that the carcasses, meat, meat food products, or meat by-products to be sold or offered for sale therefrom through commercial outlets will be wholesome and unadulterated...."6

All Federally inspected plants are exempted from this licensing requirement since similar procedures are followed by the United States Department of Agriculture. In West Virginia, however, only six of the 126 establishments listed are under Federal Inspection, according to West Virginia Department of Agriculture personnel.

\section{The Questionnaire}

Several categories of information were obtained by means of a questionnaire (Appendix) which was administered to a representative of each West Virginia slaughterer and processor. The number of head of each species slaughtered and/or processed for both commercial and custom outlets was determined for each establishment in 1971. Another category of information was used to determine which sources of live animals were more prevalent. This category was also concerned with the nature and existence of any formal contracts or agreements with live animal suppliers. Another section of the questionnaire was concerned with the number and types of outlets slaughterers and processors use to market processed meat and meat products. The last major category of information was concerned with the nature and extent of vertical integration-

3/bid., p. 354.

4 /bid.

5 /bid.

6/bid., Section 4, p. 357. 
where slaughterers or processors raise their own live animals and/or sell processed meat through their own retail stores.

\section{Locations of Slaughtering and Processing Establishments}

The various types of meat slaughtering and processing plants are distributed somewhat uniformly throughout the State. Table 1 shows the number of each of the six types of establishments and the counties where they are located. This information is also shown on the map in Figure 1. Only 10 counties had no slaughtering or processing establishments.

\section{Number of Animals Slaughtered and Processed}

Tables 2 through 12 show the number of animals of each species slaughtered and processed by each type of establishment in 1971. The number of plants conducting slaughtering and processing and the average number of head slaughtered and processed are also shown for that same time period.

The questionnaire was designed to determine the proportion of custom to self slaughtering and processing and what proportion each type of establishment contributed to the total number of animals slaughtered and processed in the State. $^{7}$

Tables 2 and 3 show that licensed commercial slaughterer-processors are primarily self rather than custom slaughterers and processors. They account for the largest share of the State's slaughter of all livestock. They also accounted for the majority of cows, calves, heifers, bulls, and hogs processed in West Virginia in 1971. Furthermore, these plants are diversified in terms of the different species slaughtered and processed. The majority of the establishments in this category slaughter and process most of the six species of livestock included in the questionnaire, although only nine of the 28 plants self slaughter and process calves (Table 3).

Licensed commercial slaughterers conduct only custom and self slaughtering operations. They custom slaughter more cows, calves, steers, and hogs than they self slaughter (Table 4). They account, however, for a relatively small percentage of the State slaughter of all species. Only one plant reported the self slaughtering of calves and only one of the eight plants in the category reported the self slaughter of bulls (Table 5 ).

Licensed commercial processors conduct only custom and self processing operations. They carry on more self processing than custom processing and account for varying proportions of the State's total processing (Table 6). None

7The term "self slaughter" is used to describe the activity of slaughtering or processing livestock which are owned by the particular establishment and which are sold as packed or processed meat on the open market. "Custom slaughtered" or processed animals are not owned by the establishment and are not sold on the open market. 
of the 16 plants reported the self processing of calves. All of the reporting plants, ${ }^{8}$ however, self processed steers which accounted for 41 per cent of the total number processed in the State (Table 7).

Custom slaughterhouses carry on both custom and self-slaughtering and processing operations. However, custom slaughtering and processing account for a significant proportion of the total number of animals slaughtered and processed (Table 8). Thirty-two per cent of the calves slaughtered in the State are slaughtered-and 33 per cent are processed-by custom slaughterhouses. Few of the $\mathbf{3 1}$ custom slaughterhouses self slaughter and process livestock, except in the case of hogs where 12 plants self slaughter and 15 plants self process (Table 9).

Custom processors conduct only custom and self processing operations. The 34 establishments custom process more calves, bulls, and hogs than they self process but they self process more cows, heifers, and steers than they custom process. Their total processing accounts for a relatively small percentage of the State's total, since most of these establishments are small independent groceries (Tables 10 and 11).

Licensed commercial ham and bacon processors were not included in State totals because these establishments usually purchase from packers hams and bacon which they then process for wholesale and retail markets. In 1971, the eight reporting establishments in this category processed 18,170 hams $-9,204$ for wholesale outlets, 8,570 for retail outlets, and 396 for custom processing. These establishments reported the processing of 310 bacons-190.5 for wholesale outlets, $\mathbf{4 7 . 5}$ for retail outlets, and $\mathbf{7 2}$ for custom processing.

In Table 12 the totals for both custom and self slaughtering and processing of livestock by all reporting establishments in West Virginia in 1971 are shown. The majority of both the slaughtering and processing is self rather than custom trade. However, custom slaughtering accounted for an average of $\mathbf{2 4}$ per cent of the total State slaughter, and custom processing accounted for an average of 18 per cent of the total processing in West Virginia.

In the cases of cows, heifers, steers, and hogs, more animals were processed than were slaughtered in licensed West Virginia establishments. This implies that 25 per cent of the cows processed, 23 per cent of the heifers, 46 per cent of the steers, and 12 per cent of the hogs came from sources other than West Virginia slaughter plants.

\section{Primary Sources of Live and Slaughtered Livestock}

Table 13 shows the sources of live animals and carcasses listed as primary sources by each category of slaughtering and processing plant. Each plant was

\footnotetext{
${ }^{8}$ Sixteen of the 17 commercia! processors reported by the West Virginia Department of Agriculture to be licensed in 1971 were included in this survey.
} 
asked to list its major sources which usually consisted of one to four separate sources of supply.

Commercial slaughterer-processors used auction markets primarily. Farmers provided the next most often used source of animals. Commercial processors reported that commercial wholesalers were the most common source of carcasses. Custom slaughterhouses, in addition to performing a service for private individuals, commonly reported raising their own livestock. Custom processors most commonly performed the service for private individuals, and ham and bacon processors all reported commercial wholesalers to be their major suppliers.

Contracts and Agreements. The use of verbal agreements and written contracts has been growing in the United States livestock industry. However, the extent of the growth in many areas has not been determined. A question on this subject was therefore added to the questionnaire.

In West Virginia, only one establishment reported having a verbal agreement and only one other establishment reported the use of a written contract. These included one commercial slaughterer-processor who reported having a verbal agreement with a cattle feeder and one commercial processor who reported a written contract with packers for carcasses. In each case the agreement and contract was used to insure a more stable supply of live animals and carcasses.

Vertical Integration. This marketing practice, generally credited as insuring a more stable supply of live animals and carcasses as well as providing a stable outlet for packed and processed animals, can be defined as a situation where one person or firm owns more than one stage of the production and/or marketing process. Examples of this were evident in. this West Virginia survey. Several reporting establishments raise their own breeding stock, feeder animals, or finished animals (Table 14). There were also several firms which reported selling processed or packed meat through their own retail stores (Table 15).

Table 14 shows the number of establishments reporting a subsidiary enterprise of raising their own livestock. Licensed commercial slaughtererprocessors reported raising their own breeding stock, feeder pigs, feeder cattle, finished slaughter hogs, and finished slaughter cattle. Licensed commercial slaughterers also reported the same activities. Commercial processors, on the other hand, raised none of their own animals. However, three of these establishments reported that they slaughtered animals in their own slaughter plants (Table 13). Custom slaughterhouses reported raising their own animals in each of the listed categories. Three custom processing plants reported raising breeding stock, four reported raising feeder cattle, and one reported the finishing of slaughter cattle. Only one ham and bacon processor reported a subsidiary enterprise and in this case it was that of raising feeder cattle.

\section{Primary Outlets for Packed Processed Meat}

Table 15 shows the number of plants reporting their major outlets for 
packed and processed meat. Most plants reported several major outlets. Commercial slaughterer-processors reported their own retail stores as one of their primary outlets. This is an example of another case of vertical integration discussed earlier. These plants also reported the selling of packed and processed meat to drive-ins and restaurants. Commercial slaughterers used their own retail stores primarily. Commercial processors sold mainly to restaurants and institutions. Custom slaughterhouses and custom processing plants performed a service for individual patrons by slaughtering or processing their animals. However, three custom slaughterhouses and 16 custom processors operated their own retail stores. Ham and bacon processors sold primarily to restaurants, motels, and hotels.

\section{Production Versus Consumption of Meat in West Virginia}

One of the objectives of this report was to determine the magnitude and importance of the meat slaughtering and processing industry in West Virginia. The results of this survey were designed to be used for estimating how much of the meat consumed in the State is produced in the State and how much is acquired from outside sources.

In order to provide this estimate, the following data and assumptions were necessary:

(1) The West Virginia population in 1971 was estimated to be $1,755,000$ people. ${ }^{9}$

(2) The United States per capita consumption of meat in 1971 was estimated to be: ${ }^{10}$

\section{Beef \\ Veal \\ Pork}

Lamb and Mutton
113.0 pounds per person

2.7 pounds per person

73.0 pounds per person

3.1 pounds per person

It was assumed that West Virginia per capita consumption would be similar to the United States average.

(3) The average live weights of livestock in West Virginia in 1971 were: ${ }^{11}$

Cattle

Calves

Hogs

Sheep and Lambs
1,007 pounds per head 227 pounds per head 249 pounds per head 102 pounds per head

${ }^{9}$ Sales Management, The Marketing Magazine, Vol. 109, No. 1, New York, Bill Publications, July 10, 1972, p. B-4.

10National Food Situation, NFS-145, Economic Research Service, United States Department of Agriculture, Washington, D. C., August, 1973, p. 15.

11 Monthly Livestock Report, West Virginia Crop Reporting Service, West Virginia Department of Agriculture, January 30, 1973. 
(4) The United States average dressing yields of livestock in 1971 were: ${ }^{12}$

Cattle

59.5 per cent

Calves

56.3 per cent

Hogs

77.1 per cent

Sheep and Lambs

49.2 per cent

(5) From Table 12, the following numbers of animals were processed in West Virginia in 1971.

\begin{tabular}{lccr}
\hline \hline Unit & $\begin{array}{c}\text { Number of Head } \\
\text { Processed }\end{array}$ & $\begin{array}{c}\text { Pounds of Meat } \\
\text { Per Head }\end{array}$ & $\begin{array}{r}\text { Total Pounds of Meat } \\
\text { Processed in W. Va. }\end{array}$ \\
\hline Cattle & 104,287 & 599 & $62,407,913$ \\
Calves & 4,139 & 128 & 529,792 \\
Hogs & 101,131 & 192 & $19,417,152$ \\
Lambs & $3,400^{13}$ & 50 & 170,000 \\
\hline
\end{tabular}

The number of pounds of meat per head was determined by multiplying dressing yields (Step 4) by average live weights (Step 3). The total number of pounds processed in West Virginia was determined by multiplying the number of head processed by the number of pounds of meat per head.

(6) The total number of pounds of meat processed in West Virginia was divided by the West Virginia population to determine the number of pounds of West Virginia meat consumed per person. ${ }^{14}$

12Livestock and Meat Statistics, Stat. Bull. No. 522, Washington, D. C., E.R.S., S.R.S., A.M.S., United States Department of Agriculture, July, 1973, p. 193-194.

${ }_{13}$ Sheep and lamb processing in West Virginia was not determined by the questionnaire. In order to provide an estimate of production and consumption, however, the figure of 3,400 lambs slaughtered in West Virginia in 1971 was used from Monthly Livestock Report, op. cit. It should also be noted that on-the-farm slaughter of livestock was omitted from the analysis.

${ }^{14}$ Since only six of the 126 slaughtering and processing firms in West Virginia were Federally inspected, it was assumed that all meat produced in West Virginia was consumed in West Virginia. Non-Federally inspected meat may not cross state lines according to Federal law. 


\begin{tabular}{lccr}
\hline \hline Unit & $\begin{array}{c}\text { Processed Meat } \\
\text { in W. Va. } \\
\text { Per Person }\end{array}$ & $\begin{array}{c}\text { U.S. Average } \\
\text { Meat Consumption } \\
\text { Per Person }\end{array}$ & $\begin{array}{r}\text { Meat Consumed but } \\
\text { not Produced in } \\
\text { W. Va. Per Person }\end{array}$ \\
\hline Cattle & 35.19 & Pounds & \\
Calves & 0.30 & 113.0 & 77.81 \\
Hogs & 10.94 & 2.7 & 2.41 \\
Lambs & 0.10 & 73.0 & 62.06 \\
\hline
\end{tabular}

The amount of meat consumed but not produced in West Virginia was determined by taking the difference between the United States average per capita consumption and the West Virginia per capita production of processed meat.

(7) Assuming the deficit (amount of meat consumed but not produced in West Virginia) was made up by processed animals from out-of-state the total number of processed animals "imported" was determined by first multiplying the deficit per capita consumption by the number of people in West Virginia. This total number of pounds imported was then divided by the number of pounds of meat per head from Step 5 to determine the number of processed animals that were brought in from outside West Virginia:

\begin{tabular}{|c|c|c|c|c|c|c|c|c|}
\hline Unit & $\begin{array}{c}\text { Meat Consumed } \\
\text { but not } \\
\text { Produced in } \\
\text { West Virginia } \\
\text { (Per Person) }\end{array}$ & . & $\begin{array}{l}\text { West Virginia } \\
\text { Population } \\
\text { in } 1971\end{array}$ & $\begin{array}{c}\text { Total } \\
\text { Pounds } \\
\text { Imported }\end{array}$ & & $\begin{array}{l}\text { Pounds } \\
\text { of Meat } \\
\text { Per Head } \\
\text { Processec }\end{array}$ & & $\begin{array}{l}\text { Number of } \\
\text { Processed } \\
\text { Animals } \\
\text { Imported }\end{array}$ \\
\hline Cattle & 77.81 & $\mathrm{x}$ & $1,775,000=$ & $138,112,750$ & $\div$ & 599 & $=$ & 230,572 \\
\hline Calves & 2.40 & $x$ & $1,775,000=$ & $4,260,000$ & $\div$ & 128 & $=$ & 33,281 \\
\hline Hogs & 62.06 & $\mathrm{X}$ & $1,775,000=$ & $110,156,500$ & $\div$ & 192 & $=$ & 573,732 \\
\hline Lambs & 3.00 & $x$ & $1,775,000=$ & $5,325,000$ & $\div$ & $50=$ & $=$ & 106,500 \\
\hline
\end{tabular}

(8) The number of processed animals brought in from out-of-state can then * be compared to the number of animals processed within West Virginia:

15 From Step 2 above. 
Number of Animals

Processed in

Unit West Virginia ${ }^{16}$
* Number of Animals

Which were Estimated

to be Imported
Animals Estimated

to be Consumed

in West Virginia

in 1971

\begin{tabular}{lrrrrr}
\hline & Number & $\begin{array}{c}\text { Per Cent of } \\
\text { Total }\end{array}$ & Number & $\begin{array}{c}\text { Per Cent of } \\
\text { Total }\end{array}$ & Number \\
\hline Cattle & 104,287 & 31 & 230,572 & 69 & 334,859 \\
Calves & 4,139 & 11 & 33,281 & 89 & 37,420 \\
Hogs & 101,131 & 15 & 573,732 & 85 & 674,863 \\
Lambs & 3,400 & 3 & 106,500 & 97 & 109,900 \\
\hline
\end{tabular}

West Virginia processes only an average of 18 per cent of the total meat consumed in the State. Eighty-two per cent of the processed meat is brought in from out-of-state. Furthermore, (from Table 12) the carcasses of 9,770 cattle, 4,519 heifers, 19,497 steers, and 12,056 hogs were brought from sources outside West Virginia to be processed in West Virginia plants.

※West Virginia processes a relatively small percentage of the amount of meat it consumes. There is potential for an increase in the size of the meat slaughtering and processing industry in the State as well as in the live animal production sector. In order to determine the feasibility of these implications, however, the economic efficiency of West Virginia firms must be compared to that of out-of-state competition.

Research is now underway to determine the nature of West Virginia's meat consumption behavior, and further research is planned to determine specific means of improving the slaughtering and processing sector of the State's livestock economy. 


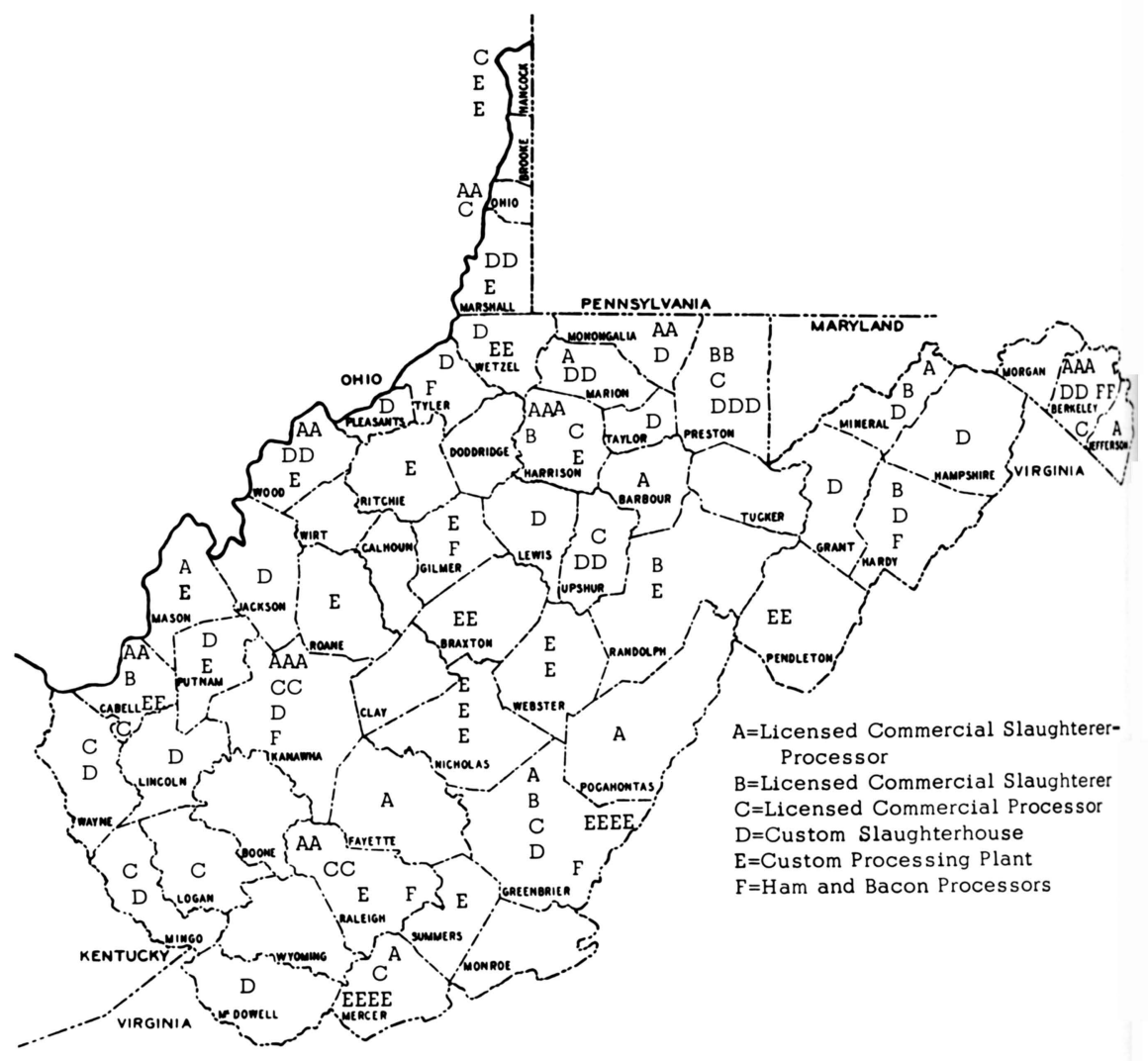

Figure 1. Location of Livestock Slaughtering and Processing Establishments by County in West Virginia, 1971. 
Location by Counties of West Virginia Livestock Slaughtering and Processing Firms by Type of Establishment, 1971.

\begin{tabular}{|c|c|c|c|c|c|c|}
\hline County & $\begin{array}{l}\text { Licensed } \\
\text { Commercial } \\
\text { Slaughterer- } \\
\text { Processors }\end{array}$ & $\begin{array}{l}\text { Licensed } \\
\text { Commercial } \\
\text { Slaughterers }\end{array}$ & $\begin{array}{l}\text { Licensed } \\
\text { Commercial } \\
\text { Processors }\end{array}$ & $\begin{array}{c}\text { Custom } \\
\text { Slaughterhouses }\end{array}$ & $\begin{array}{l}\text { Custom } \\
\text { Processing } \\
\text { Plants }\end{array}$ & $\begin{array}{c}\text { Ham } \\
\text { and } \\
\text { Bacon } \\
\text { Processors }\end{array}$ \\
\hline
\end{tabular}

$\begin{array}{ll}\text { Barbour } & 1 \\ \text { Berkeley } & 3\end{array}$

Berkeley

3

1

2

2

Boone

Braxton

Brooke

$\overrightarrow{\text { ज Cabell }}$

Calhoun

Clay

Doddridge

Fayette

Gilmer

Grant

Greenbrier

Hampshire

Hancock

Hardy

Harrison

Jackson

Jefferson 
Table 1 (continued)

\begin{tabular}{|c|c|c|c|c|c|c|}
\hline County & $\begin{array}{l}\text { Licensed } \\
\text { Commercial } \\
\text { Slaughterer- } \\
\text { Processors }\end{array}$ & $\begin{array}{l}\text { Licensed } \\
\text { Commercial } \\
\text { Slaughterers }\end{array}$ & $\begin{array}{l}\text { Licensed } \\
\text { Commercial } \\
\text { Processors }\end{array}$ & $\begin{array}{c}\text { Custom } \\
\text { Slaughterhouses }\end{array}$ & $\begin{array}{l}\text { Custom } \\
\text { Processing } \\
\text { Plants }\end{array}$ & $\begin{array}{c}\text { Ham } \\
\text { and } \\
\text { Bacon } \\
\text { Processors }\end{array}$ \\
\hline Kanawha & 3 & & 2 & 1 & & 1 \\
\hline Lewis & & & & 1 & & \\
\hline Lincoln & & & & 1 & & \\
\hline Logan & & & 1 & & & \\
\hline McDowell & & & & 1 & & \\
\hline Marion & 1 & & & 2 & & \\
\hline Marshall & & & & 2 & 1 & \\
\hline Mason & 1 & & & & 1 & \\
\hline Mercer & 1 & & 1 & & 4 & \\
\hline Mineral & 1 & 1 & & 1 & & \\
\hline Mingo & & & 1 & 1 & & \\
\hline Monongalia & 2 & & & 1 & & \\
\hline \multicolumn{7}{|l|}{ Monroe } \\
\hline Morgan & & & & & & \\
\hline Nicholas & & & & & 3 & \\
\hline Ohio & 2 & & 1 & & & \\
\hline Pendleton & & & & & 2 & \\
\hline Pleasants & & & & 1 & & \\
\hline Pocahontas & 1 & & & & & \\
\hline Preston & & 2 & 1 & 3 & & \\
\hline
\end{tabular}


Putnam

Raleigh

Randolph

Ritchie

Roane

Summers

Taylor

Tucker

Tyler

Upshur

Wayne

Webster

Wetzel

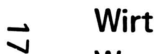

Wood

Wyoming

Total
2

1

1

1
1

1

1

1

1

1

2

2

12

2

1

2

28 
TABLE 2

Total and Proportional Custom and Self Slaughtering and Processing of Livestock by 28 Licensed Commercial Slaughterer-Processors in West Virginia, 1971.

\begin{tabular}{|c|c|c|c|c|c|c|}
\hline \multirow[b]{2}{*}{ Species } & \multicolumn{2}{|c|}{ Custom } & \multicolumn{2}{|c|}{ Self } & \multicolumn{2}{|c|}{ Total } \\
\hline & Number & $\begin{array}{l}\text { Per Cent } \\
\text { of Total }\end{array}$ & Number & $\begin{array}{l}\text { Per Cent } \\
\text { of Total }\end{array}$ & Number & $\begin{array}{l}\text { Per Cent } \\
\text { of State }\end{array}$ \\
\hline \multicolumn{7}{|c|}{ Slaughtered } \\
\hline Cows & 1,920 & 8 & 23,674 & 92 & 25,594 & 89 \\
\hline Calves & 770 & 34 & 1,515 & 66 & 2,285 & 53 \\
\hline Heifers & 1,917 & 16 & 9,858 & 84 & 11,775 & 79 \\
\hline Steers & 1,968 & 11 & 15,612 & 89 & 17,580 & 77 \\
\hline Bulls & 250 & 8 & 3,032 & 92 & 3,282 & 82 \\
\hline Hogs & 4,685 & 6 & 68,807 & 94 & 73,492 & 83 \\
\hline \multicolumn{7}{|c|}{ Processed } \\
\hline Cows & 1,734 & 7 & 23,774 & 93 & 25,508 & 66 \\
\hline Calves & 653 & 30 & 1,515 & 70 & 2,168 & 52 \\
\hline Heifers & 1,599 & 14 & 9,799 & 86 & 11,398 & 59 \\
\hline Steers & 1,677 & 10 & 15,591 & 90 & 17,268 & 41 \\
\hline Bulls & 194 & 6 & 3,032 & 94 & 3,226 & 81 \\
\hline Hogs & 4,572 & 6 & 72,230 & 94 & 76,802 & 76 \\
\hline
\end{tabular}




\section{TABLE 3}

Number of Licensed Commercial Slaughterer-Processors Reporting Custom and Self Slaughtering and Processing and the Average Number of Livestock Slaughtered and Processed per Plant in West Virginia, 1971. ${ }^{a}$

\begin{tabular}{|c|c|c|c|c|}
\hline \multirow[b]{2}{*}{ Species } & \multicolumn{2}{|c|}{ Custom } & \multicolumn{2}{|r|}{ Self } \\
\hline & $\begin{array}{c}\text { Number of } \\
\text { Plants }\end{array}$ & $\begin{array}{c}\text { Average Number } \\
\text { of Head }\end{array}$ & $\begin{array}{c}\text { Number of } \\
\text { Plants }\end{array}$ & $\begin{array}{c}\text { Average Number } \\
\text { of Head }\end{array}$ \\
\hline \multicolumn{5}{|c|}{ Slaughtered } \\
\hline Cows & 18 & 107 & 22 & 1,076 \\
\hline Calves & 14 & 55 & 9 & 168 \\
\hline Heifers & 24 & 80 & 24 & 411 \\
\hline Steers & 23 & 86 & 23 & 679 \\
\hline Bulls & 17 & 15 & 17 & 178 \\
\hline Hogs & 22 & 213 & 21 & 3,276 \\
\hline \multicolumn{5}{|c|}{ Processed } \\
\hline Cows & 18 & 96 & 22 & 1,081 \\
\hline Calves & 14 & 47 & 9 & 168 \\
\hline Heifers & 23 & 70 & 24 & 408 \\
\hline Steers & 22 & 76 & 23 & 678 \\
\hline Bulls & 14 & 14 & 17 & 178 \\
\hline Hogs & 21 & 218 & 23 & 3,140 \\
\hline
\end{tabular}

aEach of the 28 commercial slaughterer-processors reported by the West Virginia Department of Agriculture to be licensed in 1971 was included in this survey. 
TABLE 4

Total and Proportional Custom and Self Slaughtering of Livestock by Eight Licensed Commercial Slaughterers in West Virginia, 1971.

\begin{tabular}{|c|c|c|c|c|c|c|}
\hline \multirow[b]{2}{*}{ Species } & \multicolumn{2}{|c|}{ Custom } & \multicolumn{2}{|c|}{ Self } & \multicolumn{2}{|c|}{ Total } \\
\hline & Number & $\begin{array}{l}\text { Per Cent } \\
\text { of Total }\end{array}$ & Number & $\begin{array}{l}\text { Per Cent } \\
\text { of Total }\end{array}$ & Number & $\begin{array}{l}\text { Per Cent } \\
\text { of State }\end{array}$ \\
\hline Cows & 577 & 57.0 & 432 & 43.0 & 1,009 & 4.0 \\
\hline Calves & 606 & 98.0 & 12 & 2.0 & 618 & 14.0 \\
\hline Heifers & 535 & 37.0 & 903 & 63.0 & 1,438 & 10.0 \\
\hline Steers & 665 & 66.0 & 347 & 34.0 & 1,012 & 4.0 \\
\hline Bulls & 30 & 37.5 & 50 & 62.5 & 80 & 2.0 \\
\hline Hogs & 2,742 & 85.0 & 496 & 15.0 & 3,238 & 4.0 \\
\hline
\end{tabular}

TABLE 5

Number of Licensed Commercial Slaughterers Reporting Custom and Self Slaughtering and the Average Number of Livestock Slaughtered Per Plant in West Virginia, 1971. ${ }^{\mathrm{a}}$

\begin{tabular}{lccccc}
\hline \hline & \multicolumn{2}{c}{ Custom } & & \multicolumn{2}{c}{ Self } \\
\cline { 2 - 3 } \cline { 5 - 6 } Species & $\begin{array}{c}\text { Number of } \\
\text { Plants }\end{array}$ & $\begin{array}{c}\text { Average Number } \\
\text { of Head }\end{array}$ & & $\begin{array}{c}\text { Number of } \\
\text { Plants }\end{array}$ & $\begin{array}{c}\text { Average Number } \\
\text { of Head }\end{array}$ \\
\hline Cows & 7 & & 52 & & 86 \\
Calves & 4 & 152 & & 1 & 12 \\
Heifers & 7 & 76 & & 8 & 113 \\
Steers & 7 & 95 & & 7 & 50 \\
Bulls & 4 & 8 & & 1 & 50 \\
Hogs & 7 & 392 & & 5 & 99 \\
\hline
\end{tabular}

aEach of the eight commercial slaughterers reported by the West Virginia Department of Agriculture to be licensed in 1971 was included in this survey. 
TABLE 6

Total and Proportional Custom and Self Processing of Livestock by 16 of 17 Licensed Commercial Processors in West Virginia, 1971.

\begin{tabular}{|c|c|c|c|c|c|c|}
\hline \multirow[b]{2}{*}{ Species } & \multicolumn{2}{|c|}{ Custom } & \multicolumn{2}{|c|}{ Self } & \multicolumn{2}{|c|}{ Total } \\
\hline & Number & $\begin{array}{l}\text { Per Cent } \\
\text { of Total }\end{array}$ & Number & $\begin{array}{l}\text { Per Cent } \\
\text { of Total }\end{array}$ & Number & $\begin{array}{c}\text { Per Cent } \\
\text { of State }\end{array}$ \\
\hline Cows & 192 & 3 & 7,166 & 97 & 7,358 & 19.00 \\
\hline Calves & 2 & 100 & - & - & 2 & 0.05 \\
\hline Heifers & 77 & 2 & 4,532 & 98 & 4,609 & 24.00 \\
\hline Steers & 180 & 1 & 17,326 & 99 & 17,506 & 41.00 \\
\hline Bulls & 29 & 42 & 40 & 58 & 69 & 1.74 \\
\hline Hogs & 146 & 2 & $9,156^{a}$ & 98 & $9,302^{a}$ & 9.00 \\
\hline
\end{tabular}

aSelf hog processing was reported by licensed commercial processors in the form of total pounds rather than the total number of head. In order, therefore, to maintain consistency with the rest of the data in this report, total poundage was converted to number of head processed in the following manner:

1. The average dressing yield of hogs in the United States in 1971 was 77.1 per cent (Livestock and Meat Statistics, Statistical Bulletin 522, E.R.S., S.R.S., A.M.S., United States Department of Agriculture, July, 1973, p. 194).

2. The average liveweight of hogs slaughtered in West Virginia commercial plants in 1971 was 249 pounds (Monthly Livestock Report, West Virginia Crop Reporting Service, West Virginia Department of Agriculture, January 30, 1973).

3. $1,757,840$ pounds were reported to have been processed in 1971. This figure converts to 9,156 head, based on the assumptions of a 77.1 per cent dressing yield and 249 pounds average liveweight.

\section{TABLE 7}

Number of Licensed Commercial Processors Reporting Custom and Self Processing and the Average Number of Livestock Processed Per Plant in West Virginia, 1971. ${ }^{a}$

\begin{tabular}{lccccc}
\hline \hline & \multicolumn{2}{c}{ Custom } & & \multicolumn{2}{c}{ Self } \\
\cline { 2 - 3 } \cline { 5 - 6 } Species & $\begin{array}{c}\text { Number of } \\
\text { Plants }\end{array}$ & $\begin{array}{c}\text { Average Number } \\
\text { of Head }\end{array}$ & & $\begin{array}{c}\text { Number of } \\
\text { Plants }\end{array}$ & $\begin{array}{c}\text { Average Number } \\
\text { of Head }\end{array}$ \\
\hline Cows & 7 & & & 11 & 651 \\
Calves & 1 & 27 & & - & - \\
Heifers & 5 & 15 & & 11 & 412 \\
Steers & 5 & 36 & & 16 & 1,083 \\
Bulls & 3 & 10 & & 2 & 20 \\
Hogs & 4 & 37 & & $15^{\mathrm{b}}$ & $610^{\mathrm{b}}$ \\
\hline
\end{tabular}

aSixteen of the 17 commercial processors reported by the West Virginia Department of Agriculture to be licensed in 1971 were included in this survey.

bsee footnote a, Table 6 . 
TABLE 8

Total and Proportional Custom and Self Slaughtering and Processing of Livestock by 31 Custom Slaughterhouses in West Virginia, 1971.

\begin{tabular}{|c|c|c|c|c|c|c|}
\hline \multirow[b]{2}{*}{ Species } & \multicolumn{2}{|c|}{ Custom } & \multicolumn{2}{|c|}{ Self } & \multicolumn{2}{|c|}{ Total } \\
\hline & Number & $\begin{array}{l}\text { Per Cent } \\
\text { of Total }\end{array}$ & Number & $\begin{array}{l}\text { Per Cent } \\
\text { of Total }\end{array}$ & Number & $\begin{array}{l}\text { Per Cent } \\
\text { of State }\end{array}$ \\
\hline \multicolumn{7}{|c|}{ Slaughtered } \\
\hline Cows & 2,101 & 99.0 & 20 & 1.0 & 2,121 & 7.0 \\
\hline Calves & 1,374 & 99.6 & 6 & 0.4 & 1,380 & 32.0 \\
\hline Heifers & 1,475 & 91.0 & 143 & 9.0 & 1,618 & 11.0 \\
\hline Steers & 4,173 & 95.0 & 208 & 5.0 & 4,381 & 19.0 \\
\hline Bulls & 629 & 98.0 & 10 & 2.0 & 639 & 16.0 \\
\hline Hogs & 12,176 & 99.0 & 169 & 1.0 & 12,345 & 14.0 \\
\hline \multicolumn{7}{|c|}{ Processed } \\
\hline Cows & 2,056 & 90.0 & 230 & 10.0 & 2,286 & 6.0 \\
\hline Calves & 1,375 & 99.6 & 6 & 0.4 & 1,381 & 33.0 \\
\hline Heifers & 1,240 & 83.0 & 262 & 17.0 & 1,502 & 8.0 \\
\hline Steers & 4,020 & 92.0 & 342 & 8.0 & 4,362 & 10.0 \\
\hline Bulls & 609 & 98.0 & 10 & 2.0 & 619 & 16.0 \\
\hline Hogs & 10,869 & 95.0 & 531 & 5.0 & 11,400 & 11.0 \\
\hline
\end{tabular}


TABLE 9

Number of Custom Slaughterhouses Reporting Custom and Self Slaughtering and Processing and the Average Number of Livestock Slaughtered and Processed per Plant in West Virginia, 1971. ${ }^{\mathrm{a}}$

\begin{tabular}{lcccc}
\hline \hline & \multicolumn{2}{c}{ Custom } & & \multicolumn{2}{c}{ Self } \\
\cline { 2 - 3 } \cline { 5 - 5 } Species & $\begin{array}{c}\text { Number of } \\
\text { Plants }\end{array}$ & $\begin{array}{c}\text { Average Number } \\
\text { of Head }\end{array}$ & $\begin{array}{c}\text { Number of } \\
\text { Plants }\end{array}$ & $\begin{array}{c}\text { Average Number } \\
\text { of Head }\end{array}$ \\
\hline Cows & 27 & Slaughtered & & \\
Calves & 23 & 78 & 1 & 20 \\
Heifers & 27 & 60 & 1 & 6 \\
Steers & 29 & 55 & 7 & 20 \\
Bulls & 24 & 144 & 8 & 26 \\
Hogs & 30 & 26 & 1 & 10 \\
& & 406 & 12 & 14 \\
& & & & \\
Cows & 25 & 82 & 3 & 77 \\
Calves & 22 & 63 & 2 & 3 \\
Heifers & 25 & 50 & 9 & 29 \\
Steers & 27 & 149 & 12 & 29 \\
Bulls & 24 & 25 & 1 & 35 \\
Hogs & 28 & 388 & & \\
\hline
\end{tabular}

aEach of the 31 custom slaughterers reported by the West Virginia Department of Agriculture to be in operation in 1971 was included in this survey. 


\section{TABLE 10}

Total and Proportional Custom and Self Processing of Livestock By 34 Custom Processors in West Virginia, 1971.

\begin{tabular}{|c|c|c|c|c|c|c|}
\hline \multirow[b]{2}{*}{ Species } & \multicolumn{2}{|c|}{ Custom } & \multicolumn{2}{|c|}{ Self } & \multicolumn{2}{|c|}{ Total } \\
\hline & Number & $\begin{array}{l}\text { Per Cent } \\
\text { of Total }\end{array}$ & Number & $\begin{array}{l}\text { Per Cent } \\
\text { of Total }\end{array}$ & Number & $\begin{array}{l}\text { Per Cent } \\
\text { of Total }\end{array}$ \\
\hline Cows & 1,084 & 32 & 2,258 & 68 & 3,342 & 9 \\
\hline Calves & 588 & 100 & - & - & 588 & 14 \\
\hline Heifers & 909 & 49 & 932 & 51 & 1,841 & 10 \\
\hline Steers & 1,257 & 38 & 2,077 & 62 & 3,334 & 8 \\
\hline Bulls & 58 & 98 & 1 & 2 & 59 & 1 \\
\hline Hogs & 2,564 & 71 & 1,063 & 29 & 3,627 & 4 \\
\hline
\end{tabular}

\section{TABLE 11}

Number of Custom Processors Reporting Custom and Self Processing and the Average Number of Livestock Processed per Plant in West Virginia, 1971. ${ }^{\mathrm{a}}$

\begin{tabular}{lccccc}
\hline \hline & \multicolumn{2}{c}{ Custom } & & \multicolumn{2}{c}{ Self } \\
\cline { 2 - 3 } \cline { 5 - 6 } Species & $\begin{array}{c}\text { Number of } \\
\text { Plants }\end{array}$ & $\begin{array}{c}\text { Average Number } \\
\text { of Head }\end{array}$ & & $\begin{array}{c}\text { Number of } \\
\text { Plants }\end{array}$ & $\begin{array}{c}\text { Average Number } \\
\text { of Head }\end{array}$ \\
\hline Cows & 25 & 43 & & 12 & 188 \\
Calves & 17 & 35 & & - & - \\
Heifers & 27 & 34 & & 11 & 85 \\
Steers & 32 & 39 & & 18 & 115 \\
Bulls & 12 & 5 & 1 & 1 \\
Hogs & 31 & 83 & 13 & 82 \\
\hline
\end{tabular}

aEach of the 34 custom processors reported by the West Virginia Department of Agricul. ture to be in operation in 1971 was included in this survey. 


\section{TABLE 12}

Total and Proportional Custom and Self Slaughtering and Processing of Livestock by all Reporting Establishments ${ }^{a}$ in West Virginia, 1971.

\begin{tabular}{|c|c|c|c|c|c|}
\hline \multirow[b]{2}{*}{ Species } & \multicolumn{2}{|c|}{ Custom } & \multicolumn{2}{|c|}{ Self } & \multirow[b]{2}{*}{$\begin{array}{c}\text { Total } \\
\text { Number }\end{array}$} \\
\hline & Number & $\begin{array}{l}\text { Per Cent } \\
\text { of Total }\end{array}$ & Number & $\begin{array}{l}\text { Per Cent } \\
\text { of Total }\end{array}$ & \\
\hline \multicolumn{6}{|c|}{ Slaughtered } \\
\hline Cows & 4,598 & 16 & 24,126 & 84 & 28,724 \\
\hline Calves & 2,750 & 64 & 1,533 & 36 & 4,283 \\
\hline Heifers & 3,927 & 26 & 10,904 & 74 & 14,831 \\
\hline Steers & 6,806 & 30 & 16,167 & 70 & 22,973 \\
\hline Bulls & 909 & 23 & 3,092 & 77 & 4,001 \\
\hline Hogs & 19,603 & 22 & 69,472 & 78 & 89,075 \\
\hline \multicolumn{6}{|c|}{ Processed } \\
\hline Cows & 5,066 & 13 & 33,428 & 87 & 38,494 \\
\hline Calves & 2,618 & 63 & 1,521 & 37 & 4,139 \\
\hline Heifers & 3,825 & 20 & 15,525 & 80 & 19,350 \\
\hline Steers & 7,134 & 17 & 35,336 & 83 & 42,470 \\
\hline Bulls & 890 & 22 & 3,083 & 78 & 3,973 \\
\hline Hogs & 18,151 & 18 & $82,980^{b}$ & 82 & $101,131^{b}$ \\
\hline
\end{tabular}

aThese include 28 licensed commercial slaughterer-processors, 8 licensed commercial slaughterers, 16 of 17 licensed commercial processors, 31 custom slaughterhouses, and 34 custom processors.

bSee footnote a, Table 6 for explanation of the derivation of this total. 


\section{TABLE 13}

Primary Sources of Live and Slaughtered Livestock for Slaughtering and Processing by all Reporting Establishments in West Virginia, 1971. ${ }^{a}$

\begin{tabular}{|c|c|c|c|c|c|c|}
\hline \multirow[b]{2}{*}{ Sources } & \multicolumn{6}{|c|}{ Number of Establishments Reporting Sources } \\
\hline & $\begin{array}{l}\text { Commercial } \\
\text { Slaughterer- } \\
\text { Processors }\end{array}$ & $\begin{array}{l}\text { Commercial } \\
\text { Slaughterers }\end{array}$ & $\begin{array}{c}\text { Commercial } \\
\text { Processors }\end{array}$ & $\begin{array}{c}\text { Custom } \\
\text { Slaughterhouses }\end{array}$ & $\begin{array}{l}\text { Custom } \\
\text { Processing } \\
\text { Plants }\end{array}$ & $\begin{array}{l}\text { Ham and } \\
\text { Bacon } \\
\text { Processors }\end{array}$ \\
\hline Auctions & 27 & 7 & & 3 & & \\
\hline Farmers & 10 & 3 & & & & \\
\hline Raise Own & 3 & 2 & & & & \\
\hline Slaughter Own & & & 3 & 12 & & \\
\hline \multicolumn{7}{|l|}{ Other Slaughter } \\
\hline Plant & & & 1 & & 1 & \\
\hline \multicolumn{7}{|l|}{ Commission } \\
\hline Buyers & 2 & & & & & \\
\hline \multicolumn{7}{|l|}{ Commercial } \\
\hline Wholesalers & & & 12 & 4 & & 8 \\
\hline \multicolumn{7}{|l|}{$\begin{array}{c}\text { Private Owners } \\
\text { for Custom }\end{array}$} \\
\hline Slaughter & & & & 31 & & \\
\hline \multicolumn{7}{|l|}{ Private Owners } \\
\hline for Custom & & & & & & \\
\hline Processing & & & & & 33 & \\
\hline
\end{tabular}

aThese include 28 licensed commercial slaughterer-processors, 8 licensed commercial slaughterers, 16 of 17 licensed commercial processors, 31 custom slaughterhouses, and 34 custom processors. Each establishment indicated its major sources of supply. In many cases there was more than one major source for a given plant. 
TABLE 14

Number of Establishments Reporting a Subsidiary Enterprise of Raising Their

Own Livestock in West Virginia, 1971.

\begin{tabular}{|c|c|c|c|c|c|c|}
\hline \multirow[b]{2}{*}{ Enterprise } & \multicolumn{6}{|c|}{ Number of Establishments } \\
\hline & $\begin{array}{l}\text { Commercial } \\
\text { Slaughterer- } \\
\text { Processors }\end{array}$ & $\begin{array}{l}\text { Commercial } \\
\text { Slaughterers }\end{array}$ & $\begin{array}{l}\text { Commercial } \\
\text { Processors }\end{array}$ & $\begin{array}{c}\text { Custom } \\
\text { Slaughterhouses }\end{array}$ & $\begin{array}{l}\text { Custom } \\
\text { Processing } \\
\text { Plants }\end{array}$ & $\begin{array}{l}\text { Ham and } \\
\text { Bacon } \\
\text { Processors }\end{array}$ \\
\hline Breeding Stock & 7 & 2 & 0 & 10 & 3 & 0 \\
\hline Feeder Pigs & 3 & 1 & 0 & 1 & 0 & 0 \\
\hline Feeder Cattle & 7 & 3 & 0 & 8 & 4 & 1 \\
\hline \multicolumn{7}{|l|}{ Finish Slaughter } \\
\hline Hogs & 7 & 1 & 0 & 3 & 0 & 0 \\
\hline \multicolumn{7}{|l|}{ Finish Slaughter } \\
\hline Cattle & 8 & 5 & 0 & 1 & 1 & 0 \\
\hline
\end{tabular}


TABLE 15

Primary Outlets for Packed and Processed Meat by all Reporting Establishments in in West Virginia, 1971.

\begin{tabular}{|c|c|c|c|c|c|c|}
\hline \multirow[b]{2}{*}{ Outlet } & \multicolumn{6}{|c|}{ Number of Establishments Reporting Outlets } \\
\hline & $\begin{array}{l}\text { Commercial } \\
\text { Slaughterer- } \\
\text { Processors }\end{array}$ & $\begin{array}{l}\text { Commercial } \\
\text { Slaughterers }\end{array}$ & $\begin{array}{l}\text { Commercial } \\
\text { Processors }\end{array}$ & $\begin{array}{c}\text { Custom } \\
\text { Slaughterhouses }\end{array}$ & $\begin{array}{l}\text { Custom } \\
\text { Processing } \\
\text { Plants }\end{array}$ & $\begin{array}{l}\text { Ham and } \\
\text { Bacon } \\
\text { Processors }\end{array}$ \\
\hline \multicolumn{7}{|l|}{ Own Retail } \\
\hline Store & 13 & 4 & & 3 & 16 & \\
\hline Chain Stores & 3 & 1 & & & & \\
\hline Drive-Ins & 10 & & 9 & & & \\
\hline Restaurants & 17 & & 15 & & & 7 \\
\hline \multicolumn{7}{|l|}{ Motels and } \\
\hline Hotels & 3 & & 7 & & & 6 \\
\hline \multicolumn{7}{|l|}{ Custom for } \\
\hline Home Freezers & 1 & 1 & & 30 & 31 & \\
\hline Institutions & 2 & & 11 & & & 2 \\
\hline \multicolumn{7}{|l|}{ Jobbers and } \\
\hline Wholesalers & 2 & 2 & & & 1 & \\
\hline
\end{tabular}




\section{LITERATURE CITED}

Sales Management, The Marketing Magazine, Vol. 109, No. 1, New York: Bill Publications, July 10, 1972.

United States Department of Agriculture, Livestock and Meat Statistics, Statistical Bulletin No. 522, E. R. S., S. R. S., A. M. S., Washington, D. C., U. S. Government Printing Office, July 1973.

National Food Situation, NFS-145, E. R. S., Washington, D. C., United States Government Printing Office, August 1973.

West Virginia Code, Chapter 19, Article 2-B, Section 2, Vol. 7, 1971 Replacement Volume, Charlottesville, Virginia, The Michie Company, 1971.

West Virginia Department of Agriculture, Monthly Livestock Report, West Virginia Crop Reporting Service, Charleston, West Virginia, January 30, 1973. 


\section{APPENDIX (questionnaire) \\ CONFIDENTIAL \\ DIVISION OF RESOURCE MANAGEMENT \\ WEST VIRGINIA UNIVERSITY}

Record

Enumerator

Date

Name

Address

Classification

\section{Animal Output}

$\omega$

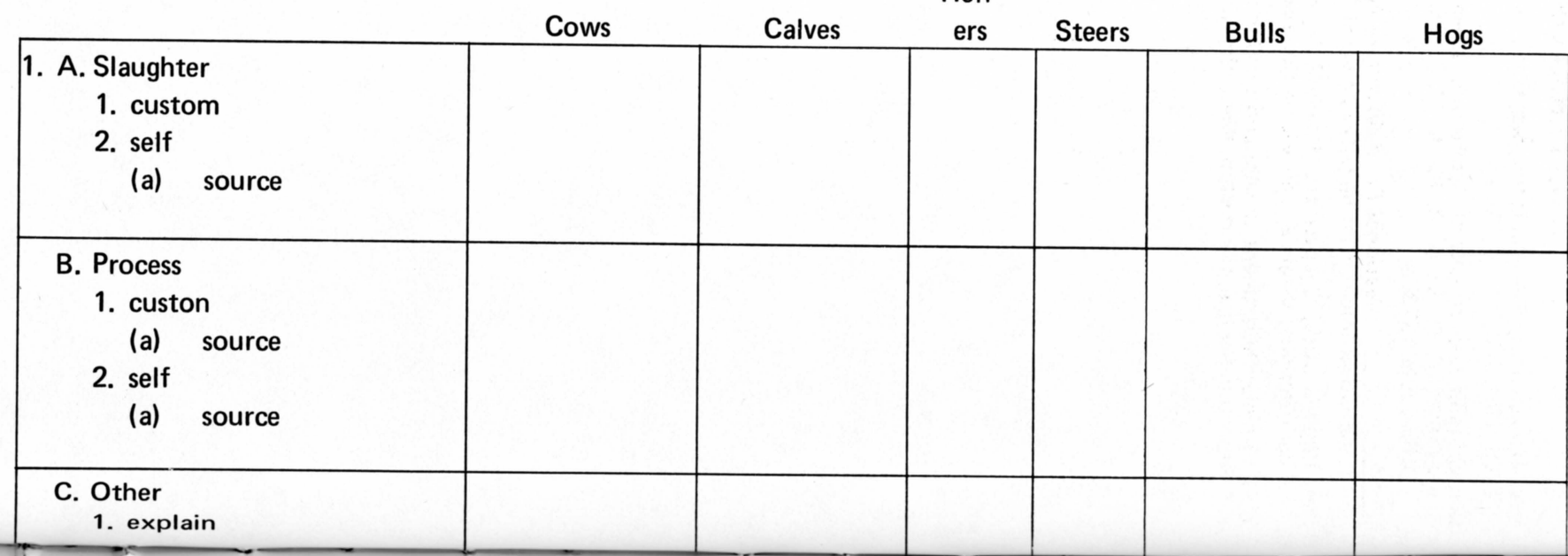


2. What is your primary outlet for slaughtered and/or processed beef? pork?

3. Do you have any formal contracts [ ]

agreements [ ] with:

Breeding stock producers [ ]

Feeder pig producers [ ]

Feeder cattle producers [ ]

Swine finishers [ ]

Cattle feeders [ ]

Feed dealers [ ]

Packers

4. Please explain why you do or do not use formal contracts or agreements:

5. When did you begin using formal contracts

6. Do you plan to initiate or expand the use of formal contracts or agreements in the near future? (Please explain fully) 
7. Do you:

\begin{tabular}{ll} 
raise breeding stock & {$[$ ] } \\
raise feeder pigs & {$[$ ] } \\
raise feeder cattle & {$[$ ] } \\
finish slaughter hogs & {$[$ ] } \\
finish slaughter cattle & {$[$ ] } \\
other & \\
\hline
\end{tabular}

(explain)

8. Please explain why you do or do not carry on any of the activities listed above:

9. When did you begin:

raising breeding stock
raising feeder pigs
raising feeder cattle
finishing slaughter hogs
finishing slaughter cattle_?
other

(explain)

10. Do you plan to initiate or expand any of the activities listed above in the immediate future? (Please explain fully). 
11. What per cent of the following items do you obtain from the indicated sources:

Formal

\section{Contract}

\begin{tabular}{l|l|l|l}
\hline & & & Contract \\
Breeding stock & & & \\
\hline Feeder pigs & & & \\
\hline Feeder cattle & & & \\
\hline Slaughter hogs & & & \\
\hline Slaughter cattle & & & \\
\hline Feed & & & \\
\hline Other & & & \\
\hline
\end{tabular}

\section{(Notes)}

12. If no copy(ies) of your contract(s) is(are) available, please complete applicable portions of the remainder of this schedule. 
13. General requirements of Contract - complete one for each species and type of contract.

\section{Production items}

\begin{tabular}{|c|c|c|c|c|c|}
\hline \multirow[b]{2}{*}{ Production Item } & \multicolumn{3}{|c|}{ Provided by - } & & \multirow[b]{2}{*}{ Notes } \\
\hline & $\begin{array}{lc} & \text { Con- } \\
: & \text { tractee }\end{array}$ & & $\begin{array}{l}\text { Con- } \\
\text { tractor }\end{array}$ & : & \\
\hline & : & : & & $:$ & \\
\hline \multicolumn{6}{|c|}{ Physical facilities------------- : } \\
\hline & : & : & & : & \\
\hline \multicolumn{6}{|c|}{ Labor-1-1.-- } \\
\hline & $:$ & $:$ & & $:$ & Basis of charge to contractee \\
\hline \multicolumn{6}{|c|}{ 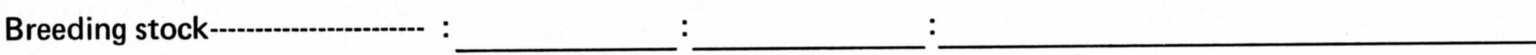 } \\
\hline \multirow{2}{*}{\multicolumn{6}{|c|}{ Utilities-_- }} \\
\hline & & & & & Charge to contractee \\
\hline \multicolumn{6}{|c|}{ 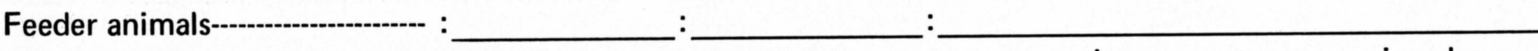 } \\
\hline & : & : & & : & Interest rate or carrying charge \\
\hline \multirow{3}{*}{$\begin{array}{l}\text { Credit for feeder } \\
\text { animals-- }\end{array}$} & : & $:$ & & : & \\
\hline & $:$ & $\therefore$ & & $\therefore$ & \\
\hline & : & : & & $:$ & Charge to contractee \\
\hline \multicolumn{5}{|c|}{ Feed-1 } & Interest rate or carrying charge \\
\hline Credit for feed---- & : & $:$ & & : & 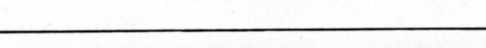 \\
\hline
\end{tabular}




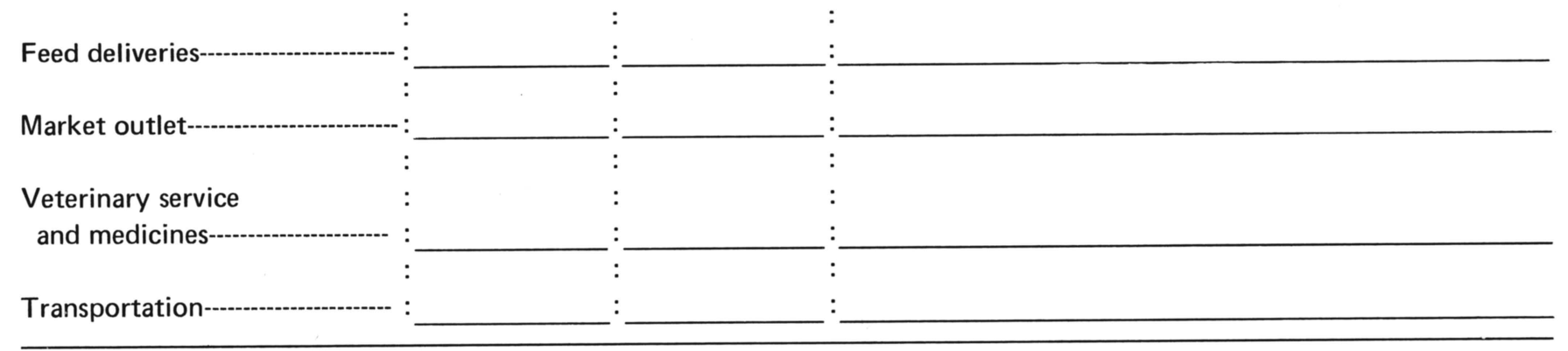

G 14. What basis is used for paying the contractee? Explain in complete detail. 
[Blank Page in Original Bulletin] 